\title{
The Aristotelian Principle in Mill and Kant
}

\author{
By William O'Meara*
}

John Rawls has identified a principle which he calls 'The Aristotelian Principle (Rawls, 1971, p.427).' Although it is not necessarily true for all people, generally we may say that most people will prefer to express in action those abilities which are more challenging to realize and that people will enjoy that expression even more, the more difficult that they are to realize. Furthermore they will find both respect for themselves and for others in a community of those who strive to develop such a challenging goal of advancing, for example, human knowledge of higher mathematics. This Aristotelian Principle is a general tendency of human nature which we can find in key aspects of the ethics of Mill and Kant. We can find the key points of the Aristotelian Principle in Mill's conception of the moral community and the moral person. First, human beings prefer the higher pleasures rather than the lower pleasures. Second, among these higher pleasures we find especially the higher challenge of living the difficult and higher life of virtue for the sake of both others and the self. Just as Aristotle cannot prove that his Principle must be true, neither can Mill prove either of these two points he has affirmed. Kant's consideration of the proposed action of failing to develop one's talents allows us to see the Aristotelian Principle at work at the heart of Kant's ethics because Kant undercuts his own a priori application of Humanity as an End-in-Itself because he sees no direct harm to humanity when one fails to develop one's own talents. Consequently, in the ethics of both Kant and Mill, the Aristotelian Principle cannot be proven as an a priori principle, but is to be affirmed as a deeply felt preference rooted in human nature's empirical desire to advance both self and others.

John Rawls has identified a principle implicit in Aristotle's analysis of human nature and behavior which he calls 'The Aristotelian Principle (Rawls, 1971, p.427).' This principle of deep motivation affirms that 'other things equal, human beings enjoy the exercise of their realized capacities (their innate or trained abilities), and [that] this enjoyment increases the more the capacity is realized, or the greater its complexity (Rawls, 1971, p.427).' Although it is not necessarily true for all people, generally we may say that most people will prefer to express in action those abilities which are more challenging to realize and that people will enjoy that expression even more, the more difficult that

${ }^{*}$ Professor, Department of Philosophy and Religion, James Madison University, USA. 
those activities are to realize. For example, a mathematician will enjoy doing geometry more than doing arithmetic, and even more, a mathematician will enjoy breaking new ground in the mathematics of infinities, as Cantor did, rather than merely repeating and teaching the insights of Newton and Leibniz on calculus.

Rawls notes the importance of self-respect as a primary good for the self in the expression of the Aristotelian Principle in our behavior. To understand this point, we may offer an analysis of someone who is a wastrel, a good-fornothing as contrasted with someone who exemplifies the Aristotelian Principle. A wastrel has no challenging goal to realize, such as contributing to the advancement of higher mathematics, and also has no effective work habits of having learned algebra, geometry, calculus, and many other disciplines of higher mathematics which would enable a person to be able to make a lasting contribution to this project. In contrast, one who lives by the Aristotelian Principle in the study of mathematics will have a challenging goal, perhaps that of contributing to the advancement of human knowledge, and will also have developed the continuing means of practicing the mastery of mathematics. In contrast with the good-for nothing who has no challenging end and no appropriate mastery of a means to realize this end, this mathematician has both a challenging end and a continuing mastery of the difficult means appropriate for achieving this end (Rawls, 1971, p.440).

Most importantly, this mathematician's self-respect, founded in both a challenging end and a challenging means, occurs best in a community of mathematicians who themselves can appreciate both the true difficulty of a great contribution to mathematics and the difficult means of developing the mastery of mathematics hitherto which sets the groundwork for the possibility for a new contribution to the field. The fact that other mathematicians value both one's own goal of contributing to the advancement of mathematics and the difficult means of striving towards that goal helps to contribute to one's own valuation of the worthwhileness of one's goal and of the difficult means. No person's estimate of the person's own self-respect is an island unto itself, but we are all intertwined in this community, for example, of mathematicians, and the mutual appreciation of each other's contributions reinforces our own appreciation and valuation of our selves. In summary, the conditions for persons respecting themselves and one another require that the fundamental goals of our actions be well thought out and complementary to each other so that, for example, the contributions of various members of the community can fit together in such a way that one scholar advances algebra, another geometry, a third calculus, and a fourth who teaches beginning students of higher mathematics subjects such as algebra, geometry, and calculus. These goals would fit together well and not thwart various goals of other scholars. Each one in the community of scholars both would appreciate the worthwhileness of the various goals sought in the field of study and also would appreciate the challenging means practiced by all as required to achieve their valuable goals (Rawls, 1971, p.441). 
We turn now to an examination of the presence of the Aristotelian Principle in the ethics of John Stuart Mill. Mill follows the general principle of Utilitarianism, namely, that those acts are right which lead to the greatest happiness, that is, the reduction of pain and the increase of pleasure, for the greatest number of people. Mill understands this goal of the pursuit of happiness as grounded in our experience of all our desires but not as an evidence which is absolutely unchallengeable. Happiness is the avoidance of pain and experiencing of pleasure. These two are the only things desirable as ends for people. Mill does not prove this definition but tries to show that this sense of happiness is what experience discloses. There are rational grounds (evidence from experience but not proof that is unchallengeable) for accepting the principle of morals. These rational grounds are the analysis of human experience to show that in fact we do only seek happiness as the only end of human action. Human nature is so constituted as to desire nothing which is not either a part of happiness or a means to happiness. For people desire nothing but pleasure. The experience of the self shows that desiring a thing and finding it pleasant are inseparable phenomena or two aspects of one and the same overall experience (Mill, 1879, ch. 2).

So far, Mill has affirmed that humans have a general desire for happiness, but has not disclosed how the key points of the Aristotelian Principle are involved in his full conception of happiness. It is in his discussion of the quality of pleasures, as opposed to Bentham's mere consideration of the quantity of pleasures, that we can find the key points of the Aristotelian Principle. Mill writes:

If I am asked, what I mean by difference of quality in pleasures, or what makes one pleasure more valuable than another, merely as a pleasure, except its being greater in amount, there is but one possible answer. Of two pleasures, if there be one to which all or almost all who have experience of both give a decided preference, irrespective of any feeling of moral obligation to prefer it, that is the more desirable pleasure. If one of the two is, by those who are competently acquainted with both, placed so far above the other that they prefer it, even though knowing it to be attended with a greater amount of discontent, and would not resign it for any quantity of the other pleasure which their nature is capable of, we are justified in ascribing to the preferred enjoyment a superiority in quality, so far outweighing quantity as to render it, in comparison, of small account (Mill, 1879, ch. 2).

For example, if we had a scale of happiness and on one side we had a $1,000,000$ moments of a pig's pleasures but on the other side one moment of human self-awareness even with great dissatisfaction, that one moment of human self-awareness is superior in quality to any quantity of a beast's pleasures. Furthermore on this same scale, if on one side we had 1,000,000 moments of a fool's pleasures and on the other side one moment of wise self- 
awareness, that one moment of wisdom is superior in quality to any quantity of a fool's pleasures. As Mill writes: 'It is better to be a human being dissatisfied than a pig satisfied; better to be Socrates dissatisfied than a fool satisfied (Mill, 1879, ch. 2).'

How do we know there is such a superiority of pleasure? Similar to Aristotle's acceptance of the Aristotelian Principle, not as an absolute necessity in our consciousness, but as a strong orientation of our human nature to prefer to actualize the more difficult of our abilities but which we can unfortunately decline to develop, Mill's answer is that we do not know and cannot prove such a superiority, however he affirms that we feel this superiority. He writes:

Few human creatures would consent to be changed into any of the lower animals, for a promise of the fullest allowance of a beast's pleasures; no intelligent human being would consent to be a fool, no instructed person would be an ignoramus, no person of feeling and conscience would be selfish and base, even though they should be persuaded that the fool, the dunce, or the rascal is better satisfied with his lot than they are with theirs. They would not resign what they possess more than he, for the most complete satisfaction of all the desires which they have in common with him... A being of higher faculties requires more to make him happy, is capable probably of more acute suffering, and is certainly accessible to it at more points, than one of an inferior type; but in spite of these liabilities, he can never really wish to sink into what he feels to be a lower grade of existence (Mill, 1879, ch. 2).

The intelligent human person, the instructed person, and the person of feeling and conscience are unwilling to change places with their opposites, the fool, the ignoramus, and the rascal, because they possess a sense of dignity in their human abilities which they prefer to preserve rather than lose by being animal-like. The reason of Mill for his basic ethical principle is quite similar to Kant's reason for his basic ethical principle, the value of the human person. Both are basing moral judgments on the dignity of the human person. We shall see that Kant defends this value by pure reflection, arguing that a rational, free being necessarily wills the value of every such being. However, Mill defends this value by an appeal to feeling, affirming that the human person has a sense of pride in one's independence, in one's freedom, which one prefers to keep rather than to lose by enslaving the self to the lower pleasures. If an individual rejects Kant's position, Kant tries to show that a rational rejection of the basic value of reason and choice in the person is impossible because such a rejection is irrational, inconsistent. If an individual rejects Mill's position, Mill can only say that his feelings were not properly developed.

If one were to raise the objection 'that many who are capable of the higher pleasures, occasionally, under the influence of temptation, postpone them to the lower,' Mill answers in response that: 
... such a postponement is quite compatible with a full appreciation of the intrinsic superiority of the higher. Men often, from infirmity of character, make their election for the nearer good, though they know it to be the less valuable; and this no less when the choice is between two bodily pleasures, than when it is between bodily and mental. They pursue sensual indulgences to the injury of health, though perfectly aware that health is the greater good. It may be further objected, that many who begin with youthful enthusiasm for everything noble, as they advance in years sink into indolence and selfishness. But I do not believe that those who undergo this very common change voluntarily choose the lower description of pleasures in preference to the higher. I believe that before they devote themselves exclusively to the one, they have already become incapable of the other. Capacity for the nobler feelings is in most natures a very tender plant, easily killed, not only by hostile influences, but by mere want of sustenance; and in the majority of young persons it speedily dies away if the occupations to which their position in life has devoted them, and the society into which it has thrown them, are not favourable to keeping that higher capacity in exercise. Men lose their high aspirations as they lose their intellectual tastes, because they have not time or opportunity for indulging them; and they addict themselves to inferior pleasures, not because they deliberately prefer them, but because they are either the only ones to which they have access, or the only ones which they are any longer capable of enjoying. It may be questioned whether any one who has remained equally susceptible to both classes of pleasures, ever knowingly and calmly preferred the lower; though many, in all ages, have broken down in an ineffectual attempt to combine both (Mill, 1879, ch. 2).

Mill's analysis here, quoted at length, shows the weakness of his defense of the superiority of the higher pleasure over the lower pleasures. Many people fail to choose the side of the scale of happiness that affirms the quality of human self-awareness over that of a beast's, the quality of Socratic awareness over that of the fool's, and the quality of the character of the moral person over that of the rascal's. We cannot prove the superiority of the human over the pig, the wise person over that of the fool, and the moral person over the rascal because the pig, the fool and the rascal have corrupted their feelings.

This weakness of basing morality upon what one feels and what one prefers is also illustrated in Mill's analysis of conscience when he affirms that:

...even though the moral feelings [inherent in conscience] are not innate, but acquired, they are not for that reason the less natural. It is natural to man to speak, to reason, to build cities, to cultivate the ground, though these are acquired faculties. The moral feelings are not indeed a part of our nature, in the sense of being in any 
perceptible degree present in all of us; but this, unhappily, is a fact admitted by those who believe the most strenuously in their transcendental origin. Like the other acquired capacities above referred to, the moral faculty, if not a part of our nature, is a natural outgrowth from it; capable, like them, in a certain small degree, of springing up spontaneously; and susceptible of being brought by cultivation to a high degree of development. Unhappily it is also susceptible, by a sufficient use of the external sanctions and of the force of early impressions, of being cultivated in almost any direction: so that there is hardly anything so absurd or so mischievous that it may not, by means of these influences, be made to act on the human mind with all the authority of conscience (Mill, 1879, ch. 2).

Even though moral feelings are not innate, Mill sees these moral feelings as having a solid basis in human nature. Mill finds this firm foundation in 'the social feelings of mankind; the desire to be in unity with our fellow creatures, which is already a powerful principle in human nature, and happily one of those which tend to become stronger, even without express inculcation, from the influences of advancing civilization (Mill, 1879, ch. 2). Mill envisions a gradual growth of deep moral concern for others when he writes that a person 'comes, as though instinctively, to be conscious of himself as a being who of course [Mill's emphasis] pays regard to others. The good of others becomes to him a thing naturally and necessarily to be attended to, like any of the physical conditions of our existence (Mill, 1879, ch. 2).' Moreover, Mill sees utilitarianism as a profound expression of the ethics of Jesus, as he writes:

In the golden rule of Jesus of Nazareth, we read the complete spirit of the ethics of utility. To do as one would be done by, and to love one's neighbour as oneself, constitute the ideal perfection of utilitarian morality. As the means of making the nearest approach to this ideal, utility would enjoin, first, that laws and social arrangements should place the happiness, or (as speaking practically it may be called) the interest, of every individual, as nearly as possible in harmony with the interest of the whole; and secondly, that education and opinion, which have so vast a power over human character, should so use that power as to establish in the mind of every individual an indissoluble association between his own happiness and the good of the whole; especially between his own happiness and the practice of such modes of conduct, negative and positive, as regard for the universal happiness prescribes: so that not only he may be unable to conceive the possibility of happiness to himself, consistently with conduct opposed to the general good, but also that a direct impulse to promote the general good may be in every individual one of the habitual motives of action, and the sentiments connected therewith may fill a large and prominent place 
in every human being's sentient existence. If the impugners of the utilitarian morality represented it to their own minds in this its true character, I know not what recommendation possessed by any other morality they could possibly affirm to be wanting to it: what more beautiful or more exalted developments of human nature any other ethical system can be supposed to foster, or what springs of action, not accessible to the utilitarian, such systems rely on for giving effect to their mandates.

We can recognize, then, the key points of the Aristotelian Principle in Mill's conception of the moral community and the moral person. First, human beings prefer the higher pleasures rather than the lower pleasures. Second, among these higher pleasures we find especially the higher challenge of living the difficult and higher life of virtue for the sake of both others and the self. Mill cannot prove either of these two points; indeed, people such as the fool, the ignoramus, and the rascal can, Mill affirms, live on the basis of their corrupted feelings since their habitual choices have overridden, the originally present, but weak, tendency to prefer the higher pleasures involved both personally and communally in the activities of wisdom, learning, and morality. Hence, for Mill, the Aristotelian Principle cannot be proven but is to be affirmed, especially in the moral person and moral community as a deeply felt preference rooted in human nature.

Similarly, we shall find the key points of the Aristotelian Principle in Kant's conception of the positive advancement of the welfare of persons in the moral community. Furthermore, we shall find that Kant's defense of this positive advancement of the welfare of persons rests not, as Kant claims, upon the a priori value of humanity as an end in itself not to be harmed, but, as this paper shall show, upon the emotional preference to engage in challenging development of our own abilities which can contribute both to the welfare of others and of the self.

Kant's setting of an example of an imperfect duty to the self about the moral obligation to develop one's talents occurs in his consideration of what he calls problem 3, a proposed refusal to develop one's own talents even though they might be useful to humanity's advancement. Kant's solution of this problem is not in accord with his first formulation of the categorical imperative, "Act only on that maxim where thou canst at the same time will that it should become a universal law (Kant, 1909, Section 2). For Kant admits 'that a system of nature could indeed subsist with such a universal law' in which people dedicate themselves to enjoyment rather than to development of their useful talents (Kant, 1909, Section 2). If a person is willing to universalize the maxim that a person may not develop his useful talents, then Kant's universalization test fails to show that failure to develop one's useful talents is not morally good.

Hence, Kant must appeal to the dignity of humanity as an End-in-Itself in order to solve this problem. However, in order to evaluate Kant's usage of the formula of Humanity as an end in itself, we need to emphasize that Kant 
wishes to defend the value of humanity as not based in a contingent human desire and/or in a contingent decision to value oneself as a rational and free agent. The value of humanity as an end in itself is not borrowed from experience, Kant claims, because of two reasons: 'firstly, because it is universal, applying as it does to all rational beings whatever, and experience is not capable of determining anything about them; secondly, because it does not present humanity as an end to men (subjectively), that is as an object which men do of themselves actually adopt as an end; but as an objective end, which must as a law constitute the supreme limiting condition of all our subjective ends ...' (Kant, 1909, p.49).

Recognizing that a true universal and absolute value of humanity cannot be rooted in an experiential desire, Kant affirms that the value of humanity is inherent in the very nature of rational and free agency. It is the pre-existing condition of any agency whatsoever, and it is primarily a limiting condition upon our human action. We must never violate, degrade, harm or destroy the dignity of humanity. However, Kant's full answer to the third problem acknowledges that a person might refuse to develop his talents and that this refusal does not violate humanity in one's own person as an end in itself. However Kant says that action should not only not violate humanity as an end in itself but that action should also advance this end. Hence, it is immoral not to develop one's talents when they may be useful to others.

It is clear that this solution by Kant violates his own guideline that moral decisions should not be based on the consequences of action. Kant had said that an act should not be judged in the light of the consequences or ends to be effected (Kant, 1909, Section 2). Kant had said that the principle of humanity should not be used as a positive goal but as a negative principle which prohibits actions against the value of the human being. However, Rader evaluates Kant's argument, here as needing a positive application of benefits for humanity, 'But is it possible to carry out the formula, "so act as to treat humanity, whether in your own person or in that of another, always as an end and never as a means only," without a view to the effects of actions? Must we not have some positive idea of the end of man and how to achieve them?" (Rader, p.564). For example, how do we know whether one method of education is better than another, unless we see the effects upon the development of human value? And how do we know what the conditions of political and economic freedom should be, unless we see the effects upon the development of the community and individuality and creativity?

In summary, then, Kant's solution of the problem of failing to develop one's talents for the sake of both the community and oneself goes beyond his own criteria of the Formula of Universal Law and the Formula of Humanity as an End-in-Itself. The universal law criterion fails because a person could universalize failing to develop one's own talents, Kant himself admits. And the criterion of humanity as an end in itself fails in this case because Kant has affirmed that it should only be used as an absolute, a priori value which ought never to be harmed whereas Kant himself requires in this case a positive 
application of the advancement of positive effects in increasing the value of humanity. ${ }^{1}$

This solution of the problem of failing to develop one's talents allows us, therefore, to see the Aristotelian Principle at work at the heart of Kant's ethics. Indeed, Kant is precisely considering here the development of one's talents, and such development is or should be, indeed, the deeply preferred option of humanity, Aristotle and Mill agree. Furthermore, Kant has argued even though there is no contradiction in the rational will that would not universalize development of one's talents and even though there is no direct harm to humanity when one fails to develop one's own talents. The option to develop one's talents for the sake of others and oneself is based in a contingent decision to value oneself as a rational and free agent, borrowed from experience. We could well use the words of Mill and Rawls here and acknowledge that our deeply preferred but still contingently desired preference is that most human beings would rather be wise person rather than foolish, would rather be instructed persons rather than ignoramuses, and would rather be persons of conscience and social feeling for others rather than rascals who have no moral integrity and have only contempt for others. Consequently, in the ethics of both Kant and Mill, the Aristotelian Principle cannot be proven as an a priori principle, but is to be affirmed, especially in the positive advancement of humanity both in oneself, for example, in the development of one's talents, and in the positive advancement of the moral community as our goal, both of which are a deeply felt preference rooted in human nature's empirical desire to advance both self and others.

\section{References}

Dean, R., 2009. The Formula of Humanity as an End in Itself. In: Th.E. Hill, Jr. (ed.), The Blackwell Guide to Kant's Ethics. Oxford: Blackwell Publishing.

Kant, I., 1909. Fundamental Principles of the Metaphysic of Morals Translated by Th. Kingsmill Abbott. New York: Longmans, Green, and Co. Available from: http://etext.virginia.edu/toc/modeng/public/KanFund.html

\footnotetext{
${ }^{1}$ See the evaluations by Richard Dean and Samuel J. Kerstein on the weakness of Kant's defense of the formula of humanity. See Dean, "The Formula of Humanity as an End in Itself," The Blackwell Guide to Kant's Ethics, edited by Thomas E. Hill, Jr. (Oxford: Blackwell Publishing, 2009) p. 93, where he evaluates Kant's FH as follows: 'There is a large gap to be filled in the move from saying that each agent must treat her own rational nature as an end in itself to saying that each agent must treat every rational nature as an end in itself.' See also Samuel J. Kerstein, "Deriving the Supreme Principle of Morality from Common Moral Ideals," The Blackwell Guide to Kant's Ethics, edited by Thomas E. Hill, Jr. (Oxford: Blackwell Publishing, 2009) p. 132: 'Another ... example of a principle Kant would be unable to dismiss on the basis of his criteria is the following principle of weak universalization, WU: "Act only on that maxim which, when generalized, could be a universal law." WU is not equivalent to the Formula of Universal Law. And Kant himself suggests that a maxim of non-beneficence could, when generalized, constitute a universal law...'
} 
Kerstein, S.J., 2009. Deriving the Supreme Principle of Morality from Common Moral Ideals. In: Th.E. Hill, Jr. (ed.), The Blackwell Guide to Kant's Ethics. Oxford: Blackwell Publishing.

Mill, J.S., 1879. Utilitiarianism. London: Longman, Green, and Co. Available from: http://www.gutenberg.org/files/11224/11224-h/11224-h.htm.

Rader, Melvin (1964), Ethics and the Human Community. New York: Holt, Rinehart and Winston.

Rawls, J., 1971. A Theory of Justice. Cambridge, Mass., Belknap Press of Harvard University Press. 